\title{
DRAMA AS SCIENCE DOCUMENTARY: THE ETHICS OF MAKING AND
}

'BANNING' THE BLACK POOL

\section{David Rolinson}

\section{Accepted for publication in Historical Journal of Film, Radio and Television, by Taylor \& Francis}

This article explores 'The Black Pool', a docudrama which was made for the BBC's science documentary series Horizon (BBC2, 1964-present) but never transmitted. Aiming to provide a case history of paranoid schizophrenia, Horizon commissioned Alan Plater to dramatise an 'autobiographical document' by a doctor who murdered three children in 1972. Its makers debated the most appropriate form and style, raising issues which are relevant to current documentary scholarship in ethics and affect. Similar issues were raised by BBC executives who decided not to broadcast the completed programme. This period produced several programmes which were banned, delayed or not completed, but 'The Black Pool' and the circumstances behind it are not well-known. This article draws from a range of sources, including a new interview with director Simon Campbell-Jones, previously-unseen archival documents and a viewing of the untransmitted programme, not merely to uncover a 'banning' but to reflect on ethical and affective questions in current scholarship and to address the nature of science documentary and science docudrama. The article contributes to studies of 'forgotten drama' both in terms of this unseen and largely undiscussed programme and in terms of a neglected, specialised culture of drama in documentary strands in general and science documentary strands in particular.

Made for the BBC science series Horizon (BBC2, 1964-present), 'The Black Pool' dramatised an autobiographical manuscript by a doctor who had murdered three children in a 
Blackpool hospital in 1972. Adapted by television playwright Alan Plater and directed by Horizon's series editor Simon Campbell-Jones, 'The Black Pool' was made in 1978 but has never been transmitted. This article tells the largely untold story of 'The Black Pool', drawing from a new interview with Campbell-Jones, a viewing of the untransmitted programme and archival research from the BBC Written Archives Centre and the University of Hull's Alan Plater archive at Hull History Centre.

'The Black Pool' is a 'forgotten' drama in two distinctive ways. Firstly, it demonstrates that cultures of drama operated within a range of factual series that should not be neglected by drama scholars. This article therefore addresses the value of docudrama in Horizon's specific context as a science strand. ${ }^{1}$ Though primarily a documentary series, Horizon occasionally makes dramas in order to take a different approach: therefore, in its attempt to 'explain to the general public what happens to people who get paranoid schizophrenia and how it happens', 'The Black Pool' focused on the doctor's thoughts in the months leading up to the attack, to provide 'a study, in the first person, of acute paranoid schizophrenia'. ${ }^{3}$ Secondly, the programme has been forgotten as a result of not being transmitted: this may seem a truism but The War Game (BBC 1965), Brimstone \& Treacle (BBC 1976) and Scum (BBC 1977), though banned for many years, were kept visible by their makers and critics. ${ }^{4}$ There was press coverage of 'The Black Pool' and its non-transmission at the time, and Plater's own account in New Statesman in $1980,{ }^{5}$ but it has hardly featured in subsequent work on television or untransmitted programmes. ${ }^{6}$

This article moves chronologically through key events, stepping back from this timeline to provide analytical context when important issues are raised. The article has a particular interest in how ethical considerations were discussed by programme makers, the press and executives at the BBC. 


\section{For the protection of the public: source material}

One of the key issues discussed in the creation and non-transmission of 'The Black Pool' was the social motivation of prevention. It is therefore necessary to briefly survey the events that Horizon sought to itemise and understand. The doctor, Ahmad Alami, was born in Jerusalem in 1940 into a respected family: his father was Mufti of Jerusalem. ${ }^{7}$ Following unsettled years in and out of Universities, the Jordanian Army and a German hospital, he arrived in London in March 1970. Alami studied at the Institute of Ophthalmology, worked in Rochdale and Bournemouth and started work at Blackpool Royal Victoria Hospital on 1 August $1971 .{ }^{8}$ 'The Black Pool' dramatises these events and Alami's thought process, leading up to the tragic events of 17 February 1972.

On that date, Alami stabbed two nurses and four children in the children's ward at the Royal Victoria Hospital. Three of the children died, aged four years, two years and nineteen months respectively. Arrested within twenty-four hours, Alami was charged with murder. Details emerged slowly, with speculation fuelled by press restrictions. In June, the Crown Court decided that he was unfit to plead: Alami had paranoid schizophrenia, but the hospital stated that it had not known this. There were calls for a public inquiry from the victims' parents and the press, to address a 'need to know that everything possible is being done to prevent any other tragedy of this sort. ${ }^{99}$ In October, the Secretary of State for Social Services ruled that there would not be a formal inquiry, arguing that 'no action could have prevented the tragedy' and 'there was and is no way of predicting' that he 'would become dangerous'.10 The parents responded by querying Alami's medical treatment and how he had been able to register to work in British hospitals, as part of a desire to 'ensure that this never happens again'. ${ }^{11}$ The Deputy Coroner noted that the parents did not unanimously support a formal inquiry because its result was not likely to justify the pain of going through the events and publicity again. ${ }^{12}$ This weighing of the social motivation of prevention against the emotional 
impact of revisiting traumatic events would be another key issue in 'The Black Pool' and the BBC's response to it.

In March 1973, the Blackpool attack was discussed in For the Protection of the Public, a BBC1 programme which used several cases to critically assess the General Medical Council's responses to medical misconduct. The programme comprised two sections: a documentary, which included interviews with the parents of victims, and a studio discussion chaired by Ludovic Kennedy. ${ }^{13}$ Reviewer Sean Day-Lewis observed that Blackpool provided 'the most disturbing' case study in Chris Brasher's 'firmly partial and striking filmed report' which served to 'foster unease about present procedures'. ${ }^{14}$ Newspapers observed that the programme's findings conflicted with the Secretary of State's earlier statement: for example, although medical ethics had prevented details about Alami being circulated to his superior and Blackpool's management, others at Blackpool did know and he had previously been diagnosed in the UK (after colleagues at Bournemouth expressed concerns about him) and in the Jordanian Army, when he was 'found totally unfit to practice as a doctor'. ${ }^{15}$ The Department responded by 'standing by the Minister's original statement', which the Sun criticised because 'A way MUST be found to reassure parents and the public that nothing like the Blackpool tragedy can happen again.' 16

For the Protection of the Public was researched by Susie Dewar. Conducting interviews in January and February 1973, Dewar uncovered details of Alami’s previous illnesses in 1964 and 1969, his ECT treatment in 1969, a lack of diligence in following up his references, his visits to various doctors in the UK including his diagnosis in February 1971 and the fact that during treatment in April 1971 it was clear that he was hearing voices. ${ }^{17}$ Alami stayed in touch with Dewar and later informed her about his manuscript; CampbellJones was interested in seeing it for Horizon. ${ }^{18}$ Conditionally discharged from Broadmoor in December 1976, Alami was repatriated, initially to receive treatment in a secure psychiatric 
hospital in Bethlehem. ${ }^{19}$ During a science journalists' trip to Israel, Campbell-Jones met Alami in March 1977 and accessed his manuscript, which he thought was 'electric':

Far from being the ramblings of a madman, or the excuses of a criminal, it was a clear, logical and apparently honest account of the thoughts and experiences which led him to kill the children. As a case study of paranoid schizophrenia (as he was repeatedly diagnosed) I considered it suitable for a dramatised Horizon. ${ }^{20}$

Dewar fact-checked the manuscript and Campbell-Jones took advice from institutions and relatives. By October 1977 Horizon was connected to Alami’s manuscript by contracts and by late February Plater had read it and agreed to adapt it by 31 July, ahead of planned filming between 7-27 October $1978 .^{21}$

\section{We shall be answerable: ethics and docudrama}

Plater produced a treatment and characteristically thoughtful notes for the production team addressing style, tone and outstanding issues. ${ }^{22}$ Plater's note demonstrates the importance of ethical questions in the shaping of the production. It begins:

In making this film, we shall be answerable, probably in every sense, to the parents of the children who were murdered. This being so, it is essential to know why we are doing it. In simple terms, it is an attempt to understand: to examine the step-by-step mental disintegration of a man: and, as in all tragedy, to indicate those moments when prevention might have been possible. [...] Confronted with a manuscript like Alami's, the proper human response is to ask the question Why? in the sure and certain 
knowledge that any of us, in certain circumstances, might find ourselves walking in that same valley. ${ }^{23}$

The emotive phrase 'we shall be answerable' is striking given that the programme would not be transmitted and that the controversy would involve the perceived impact on the parents. In 1980, Plater explained that:

I accepted the assignment on three main conditions. First, that under no circumstances would the killings be shown on screen; second, that the treatment of the events would be consciously low-key, restrained and "undramatic"; third, that if there were the slightest suggestion of opposition from the parents, the project would not go ahead. ${ }^{24}$

Plater's interweaving of style and real-world implications for those affected by the events raises wider ethical issues that pertain specifically to docudrama. Steven Lipkin notes the 'ethical consequences' of 'the act of re-creation', which begin with 'the very choice of subject to re-create'. After this, other decisions reveal the 'alignment' or 'proximity' of 'actuality and re-creative representation'. ${ }^{25}$ Lipkin itemises two 'warrants that allow docudramas to offer arguments by analogy'. ${ }^{26}$ The first, whether a story deserves to be told at all, can be demonstrated in relation to 'The Black Pool' in terms of Lipkin's argument about the 'rootability' of events, the extent to which the 'story subject matter has emerged from current events' and how its 'recognisability as "news" confirms its reality status'. ${ }^{27}$ Plater told the production team that it 'can be no more than a pious wish' that making the drama 'might prevent similar cases occurring', but in 'looking carefully at a particular case, we might take a hesitant half-step towards a greater understanding of the general question'.28 
The 'recognisability' of 'The Black Pool' also had potential implications, especially in relation to Lipkin's second warrant, that 'the story must be told "this" way, through recreation'. ${ }^{29}$ As Lipkin observes, those types of docudrama which use a 'based on' licence rather than an 'inspired by' licence have close 'proximity to their subjects and are governed by [strict] legal guidelines', becoming subject to 'extensive annotation documenting line-byline dialogue, and character and scene descriptions' ${ }^{30}$ As Derek Paget observes, this process of 'legalling', which is 'a kind of anticipatory defence' whereby makers verify the 'factual basis' of a docudrama, can risk stifling creativity in that the legal preference for direct demonstration may clash with writing and acting conventions which prefer concealment and subtext, hence 'the old concern that docudrama might be bad drama or bad documentary or both' ${ }^{31}$ Docudrama, in its research and planning stages and its awareness of the potential impact of transmission and reception, has 'more sensitivity to possible real-world repercussions, more direct fit with the real world, than with any other drama genre'. ${ }^{32}$ Plater's first task with the manuscript was to assess his ability to write effectively 'within the bounds of taste and the laws of libel'. ${ }^{33}$ 'The Black Pool' underwent some changes after consultation with the BBC solicitor, though as Campbell-Jones noted there was 'no intention to indict any individual' 34

Plater recalled in 1980 that 'Campbell-Jones wrote to the parents, inviting their objections, but none was forthcoming'. The programme makers insisted that they would not continue if the parents objected, but instead 'there was reason to think that they, and the Blackpool police, would welcome a re-examination of the case because of the broader implications of internal hospital security'. ${ }^{35}$ The ethical dimensions of these interweaving definitions of impact recall concepts in documentary studies. If, as Bill Nichols argues, 'an ethics of responsibility' is one of the requirements of documentary in its search for 'techniques to give cinematic embodiment to lived encounter and historical events, 
experience and reflection, research and argumentation', to whom is that responsibility owed? $?^{36}$ Richard Kilborn and John Izod note that ethical issues relate to "the way in which documentarists should behave towards the people and topics they deal with' - before, during and after filming and transmission. ${ }^{37}$ For Brian Winston, 'the legally mythic "contract with the viewer" is less important than the relationship between documentarists and participants which forms the real 'ethical key'. ${ }^{38}$

The ethical question of repercussions was part of the planning of 'The Black Pool'. When the people depicted in Hostages (ITV, 23 September 1992) objected to its existence, the media response identified a 'moral question': whether docudramas should be permitted to exploit their subjects' lives 'for the purposes of entertainment'. ${ }^{39}$ The use of the word 'entertainment' here is striking for its associations with non-'serious' forms, perpetuating a binary between documentary as objective fact and drama as subjective fiction. Even though the documentary treatment of the Blackpool events - For the Protection of the Public - was transmitted but the docudrama approach was not, this binary is unstable. Indeed, it is particularly problematic given that 'The Black Pool' is an episode of a science documentary series that has its own requirements.

\section{Perceptions: drama as science documentary}

Docudrama's affective qualities and deployment of fictive construction are not as distant from the expectations of Horizon as they may initially seem. Those features fulfil Horizon's purpose as expressed in its early days, when Aubrey Singer, the then-Head of BBC Features and Science Programmes, observed that the 'televising of science [was seen as] a process of television, subject to the principles of programme structure, and the demands of dramatic form', and its aim was 'not necessarily the propagation of science' but, like 'all broadcasting, an enrichment of the audience experience. ${ }^{40}$ Campbell-Jones noted in interview that Horizon 
is 'a lovely title' which he described to colleagues as meaning 'as far as you can see in any direction'. ${ }^{41}$ As Singer had said, Horizon explored 'the scientific attitude' and science's 'ideas and philosophies' because 'scientists themselves see science as more than an organized body of knowledge. ${ }^{42}$

Campbell-Jones noted in interview that he was 'particularly interested in autism and various other things in the mental area' and mindful that 'we hadn't done enough Horizons' on such topics. His response to Alami's manuscript and expert feedback on it as an inside view of the condition was 'That's a Horizon - we've got to tell that story'. This phrase echoes Lipkin's first warrant, but the second warrant - the suitability of docudrama for telling the story - operates in a specific context with Horizon. Campbell-Jones recalled in interview that Horizon had the budget for two docudramas per year, though rising costs had meant that those slots were not always used. Previous Horizon docudramas included the award-winning ‘Joey: The Autobiography of Joey Deacon' (BBC2, 9 December 1974), which dramatised the life story of a man with severe cerebral palsy who was unable to walk or make himself understood through speech until meeting a fellow patient who could understand him, ${ }^{43}$ and ‘The Eddystone Lights' (BBC2, 24 February 1978), Plater's account of the difficult building of three lighthouses on the dangerous Eddystone rocks. ${ }^{44}$ Reviewer Chris Dunkley observed that Plater's 'marvellously entertaining and instructive' Eddystone piece had not suffered the complaints about misleading audiences that other docudramas received for using similar techniques, arguably because of the historical distance of its topic. ${ }^{45}$ Similarly, 'the peculiar mixture of drama and re-staged actuality' in 'Joey' demonstrated that critics should not stereotype the form: '[e]ach new programme subject should be treated as a unique problem requiring a unique answer'. ${ }^{46}$ Docudramas were rare on Horizon, so 'The Black Pool' serves as a specific solution to this unique problem. 
The Horizon team anticipated potential problems with the docudrama approach, involving the very questions of affective impact which were to arise when the decision was made not to transmit it. ${ }^{47}$ Campbell-Jones 'was quite scared of it' in the sense that it involved an 'emotionally very sensitive topic'. He clarified that he 'wasn't afraid of the subject' but of 'my abilities to make a drama' since this was his first as director. It was again a question of tone: 'I wanted to underplay it, and Alan did that beautifully'. As we saw earlier, Plater shared this desire for a 'low-key, restrained and "undramatic"' approach; indeed, these qualities were characteristic of his approach to narrative throughout his career. ${ }^{48}$

'The Black Pool' is therefore simultaneously part of a science documentary series and a drama, an adaptation of a source written in the first person. In his notes to the production team, Plater stressed that:

I can only write the film my way - by selecting from the source material and organising to a pattern that reflects my preconceptions, prejudices and background. This implies a playwright's viewpoint, which will obviously be different from that of a psychiatrist, a social worker or an investigative journalist, though any discussions and research in those areas will colour the approach. [...The manuscript's] length and complexity imply considerable editing and selection, and this is where I should declare my playwright's hand. ${ }^{49}$

Plater drew from others' viewpoints - he used Dewar's research and accompanied her on research interviews - but these notes signposted his own viewpoint, seeing the story as 'a classical tragedy', with 'a range of influences and pressures [...] leading to the inevitable climax' and the sense that 'tragedy might have been averted'. 
Plater's notes argued that the piece should be 'built around one man's perception of a series of events' and this is manifested in the script in various ways. The opening scene takes place on the out-of-season Blackpool seafront: we are introduced to Alami (Marc Zuber) through a shot of the water 'making whatever abstract patterns it chooses, in tones of black and grey', as he stares at the water only to be 'yanked from whatever private dream is occupying him' by nearby sounds. ${ }^{50} \mathrm{He}$ can see other people but cannot read them. When he goes to buy a knife, he is confused by the patter of the shopkeeper who speculates on its uses: 'Sharpening pencils? Skinning rabbits? Taking little boys out of horses' hooves?' This is both comic and loaded given the tragedy to come; it is also, as Campbell-Jones observed in interview, 'very Plater-ish'.

As 'The Black Pool' moves back in time to Alami's early experiences upon arriving in the UK, his subjective perception is foregrounded by first-person voice-over and a detached style. For example, voice-over itemises his thought process when a brief conversation with a woman results in him wondering whether getting a divorce to marry her would disrupt his studies. The detached style includes initially unmotivated and unexplained quick flashbacks which accumulate and are quoted in later scenes. Alami remembers finding his wife in a state of undress, a moment which he misinterprets and which alters in its later quotation, fed by his sexual hang-ups and his erroneous conviction that she was involved in incest and that promiscuity and prostitution were tools of social control in his workplace. The latter view is part of Alami's conception of 'The System', through which various familial, sexual, social and cultural pressures escalate and coalesce. When Alami is involved in a car crash, he speculates that people place obstacles in his way in the interest of garages, but shots of this crash and the sea are quoted later as his paranoia escalates: 'The conspiracy against my life was more than I could bear. I knew the secrets of The System but I could not figure out how they wanted to kill me. ${ }^{51}$ To prepare himself, he buys a knife. 
Therefore, access to Alami's perception is conveyed not merely through voice-over dialogue adapted from the manuscript telling us what he thought but also through a style that attempts to give us an insight into his disturbed perspective. Plater's script specifies pans and zooms at particular moments and sometimes begins consecutive scenes with similar techniques in order to emphasise repetition and the closing-in of Alami's accumulating logic. Sometimes the script stipulates a point-of-view shot that we should not immediately realise is a point-of-view shot. The cumulative effect is a style that is subjective and distorted yet cold in its detachment.

The success of 'The Black Pool' depends upon the extent to which the evocation of subjective experience, by a 'playwright's hand', constitutes the effective accumulation of evidence for a documentary strand like Horizon. In interview, Campbell-Jones, as a noted documentary maker who wrote the documentary code of practice for the Director's Guild and continues to make documentaries, disagreed with the suggestion that such techniques were incompatible with the purpose of Horizon: 'Some people say nothing is objective, everything is subjective, and there's an element of truth in that'. Therefore, 'the person who makes an ordinary Horizon' uses a voice-over but 'whose viewpoint is that? It's the producer's'; similarly, these days 'all Horizons have presenters' but this 'becomes their viewpoint'. Campbell-Jones responded to Plater's definition of his 'playwright's hand' by noting that 'a playwright's point of view is to bring out the character of the person' and that this could be more objective than the viewpoint of investigative journalists faced with the same story. A deceptively complex production for Horizon, 'The Black Pool' feels documentary-like in its fictive subjectivity, its skewed perspectives, in its attempt to generate affect.

\section{'Emotional overtones': affective qualities and the 'ban'}


Complaints about 'The Black Pool' arose before filming began. The BBC was contacted by several interested parties from 1 October 1978 onwards, including politicians and a nursing representative. ${ }^{52}$ Local newspaper the Lancashire Evening Post campaigned against the programme, beginning on 3 October with the front-page story 'Amazing secret of film on butchered babies'. ${ }^{53}$ An accompanying editorial commented that there was 'little moral justification for a dramatic reconstruction of the hideous events' ${ }^{54}$ This echoed the ethical concerns expressed earlier in the production but, despite quoting Campbell-Jones, the piece misrepresented the script's tone and content and claimed that Alami was the scriptwriter. As Plater put it, 'the Horizon office' had clarified this 'but truth was clearly seen as an obstacle to be cleared on the way to a good story'. ${ }^{55}$

The piece quoted the reservations of several people, including North Fylde MP Walter Clegg, whose response included questions of form and reach: 'A dramatised reconstruction involving actors can be very dangerous. If this is to be a study of madness it would be more appropriate as a documentary for medical people and not the whole nation. ${ }^{56}$ The accompanying editorial called for Campbell-Jones to 're-think the shape of his project' or else 'his superiors should re-think it for him', since although the BBC 'should be free of censorship', it 'should also be susceptible to moral pressure' ${ }^{57}$ The following day, Home Secretary Merlyn Rees told the newspaper that 'the most I can do is bring it to the notice of the $\mathrm{BBC}$ ', since it is run by its Governors and politicians must not have powers over television. ${ }^{58}$ Further dissenting voices included Preston North MP Ron Atkins, who hoped that Rees's words would force the BBC to abandon what he saw as another example of their 'X-certificate' programming. ${ }^{59}$ On 1 November, Ian Trethowan wrote a response to a letter from Clegg: 
Horizon $[\ldots]$ is a serious, even rigorous, weekly scientific programme with a very good reputation. On this occasion, what the producer has in mind is a dramadocumentary examining [Alami's] thought processes over a period of two years before the attacks took place. The aim is a serious investigation, based on the doctor's own writings, of the thought track of a paranoid schizophrenic. [...] It is not intended that the programme should examine the attacks themselves. The dead children will not be portrayed or even named. [...] The hope is that it will help people to understand what happened and in so doing, perhaps also lessen the possibility of other attacks of the same kind. ${ }^{60}$

Trethowan's response echoes ideas from earlier in this article: the markers of rigour in the stressing of the programme's factual, investigative purpose; the social motivation of prevention with its implicit defence of the right to know; and the repetition of 'serious' which recalls the 'discourse of sobriety' with which documentary (rather than docudrama) has long been associated. ${ }^{61}$ Plater invoked similar discourses of quality television when he pointedly described Horizon as 'a regular jewel in the BBC's Annual Report' in his piece on the play's non-transmission. ${ }^{62}$

Filming took place with some institutions cooperating and others not. The conflicting accounts that had been given in the years immediately following the attack - as outlined earlier in this article - may have motivated the lack of knowledge that Campbell-Jones noted among some objectors and which partly confirmed the need for the programme. ${ }^{63}$ However, pressure escalated. The four MPs representing Blackpool and Fylde constituencies condemned the programme and, in the House of Commons, asked a question of the Health Secretary and tabled a motion asking the BBC to reconsider its decision to continue. ${ }^{64}$ In December Paul Bonner, the Head of Science and Features, sent Trethowan a draft reply to a 
further MP letter and petition. ${ }^{65}$ Bonner's note included a detailed brief by Campbell-Jones dated 1 December 1978, from which this article has often quoted, explaining the programme's origins and approaches. ${ }^{66}$

In a memo on 7 December, Bonner described 'The Black Pool' as 'a work of integrity' having now seen a rough-cut of it. Though he recognised that some 'fine judgements' might be made about elements of it, he wrote that 'there is no question of the film being referred' (that is, referred up to a superior for scrutiny and possible nontransmission). However, in the archives this memo has a pencil annotation: 'Not sent due to programme cancellation' ${ }^{67}$

In January 1979, Alasdair Milne, the Managing Director of Television, viewed 'The Black Pool' and, in Plater's words, 'Milne's report to Trethowan was apparently some way short of ecstasy'. Plater was disappointed that Milne based his judgement on 'an early roughcut version [...] lacking its final soundtrack - an unsatisfactory and unfair time to assess a piece of work consciously written, played and directed in an oblique style, shaded in grey'. ${ }^{68}$ On 5 January, Trethowan described the 'thorough reconsideration' that had taken place following various 'representations':

I am satisfied that the aims of the producer were entirely serious, and genuinely scientific, but we recognise that were such a programme to be broadcast, there would be so many emotional overtones that the serious purpose could well be obscured. We have therefore decided not to proceed with the programme. ${ }^{69}$

Milne confirmed this cancellation at the Board of Management meeting on 8 January. ${ }^{70}$ Trethowan's phrase 'emotional overtones' relates to the moment of reception and the real and/or imagined responses of those affected by the events. 'The Black Pool' was therefore 
felt to have emotional overtones - or affective qualities - beyond those of the broadcast documentary For the Protection of the Public.

There was confusion and disagreement about the reasons for this cancellation. One reason, which as far as I have been able to ascertain was not communicated to the programme makers, was given at a Board of Management meeting on 18 December 1978. This related to guidelines involving Horizon's copyright payment for rights to Alami's manuscript. ${ }^{71}$ On 1 December, the same day that Campbell-Jones noted the payments for television rights in his brief to Bonner, the press reported MP Norman Miscampbell's letter to Trethowan asking whether 'the BBC is paying Doctor Alami'. ${ }^{72}$ This explanation provides an extra dimension to the ethics debate and the programme's status somewhere between science docudrama and literary adaptation. However, it is an unstable solution because it seems not to have been mentioned again and, furthermore, the programme was still being worked on for possible transmission in 1980. Such a lengthy gestation period, with substantial revisions, was not unique - Roger Silverstone traced the difficult progress of Horizon episode 'A New Green Revolution?' from the initial idea in 1981 to broadcast in 1984 - but the circumstances of 'The Black Pool' were unusual. ${ }^{73}$ According to Plater, Milne 'agreed to reconsider the finished film' if 'additional "safeguards" were added, including 'a pre-programme Introduction by a leading Psychiatrist, clarifying its intentions, and an after-the-programme studio discussion', the latter of which Plater wryly attributed to 'the age-old BBC premise that you can get away with most things if you discuss them afterwards in a "balanced" way. ${ }^{74}$ The package would include a report from the Institute of Psychiatry which called the programme 'honest, unemotional, neither sentimental nor sensational', in short 'an excellent case history' ${ }^{75}$

In June 1979, the Daily Mail reported that Trethowan had scrapped this 'death drama' after 'strong objections from local Tory MP Walter Clegg and the parents of the dead 
children', though the quotations from Trethowan resemble his letters from January. Plater was quoted as being surprised by this news and concerned that this 'very delicate subject' was being assessed in a 'less adventurous' television climate than there had been a decade earlier. ${ }^{76}$ Later that month, the same newspaper placed the docudrama in a list of recently abandoned, banned or remounted programmes including Article Five (BBC 1975), Brimstone $\&$ Treacle, Scum and Solid Geometry. ${ }^{77}$ Or, as Plater observed in the draft version of his New Statesman piece, 'Department of consolation: when you join the banned, you mix with a very good class of writer'. ${ }^{78}$ On 15 February 1980, Milne wrote to Plater:

I have decided not to transmit it and I wanted you to know why. All along we were anxious $[\ldots]$ that a study of the case would upset the parents $[\ldots]$ and as you know, the Director General had some correspondence on that theme a year ago [...] I simply don't think that the story or the treatment has emerged in a strong enough form to contemplate the kind of distress we might cause. ${ }^{79}$

Affect here is ethical in that it is based on perceptions of the parents' responses to this treatment. As we have seen, this was also central to the programme makers' concerns. Plater replied to Milne, respecting Milne's right to make the editorial decision but reiterating his concern for the parents, and wondering whether 'the $\mathrm{BBC}$ has given way to pressure from $[\ldots]$ MPs who haven't seen the programme, but who did see some rather hysterical reports in a local newspaper' ${ }^{80}$ Milne repeated that he had 'a slightly different impression of [the parents'] attitude from the one you describe', but insisted that his decision stemmed not from the MPs but from 'the nature of the case, and the reaction that I had viewing it myself': indeed, 'the most important fact is that I just don't think it works on the screen and, being a pretty nasty case, I don't think we should go ahead and transmit it. ${ }^{, 81}$ 
Finding this letter 'vague' in its argument about merit, Campbell-Jones told Plater that 'it confirms what we suspected. The programme has been banned by mistake': it seemed that Milne was forced to make a judgement after Trethowan, under pressure, referred the programme down to him. ${ }^{82}$ In April 1980 the New Statesman published Plater's account, adding as a postscript the response they requested from Milne: 'Neither Brian Wenham [Controller of $\mathrm{BBC} 2]$ nor I thought the completed version good enough to warrant the distress we remained certain it would cause, if it were transmitted' ${ }^{83}$ In July, Plater, Bonner and others discussed the decision with Wenham; Plater expressed a desire to move on, while Bonner hoped that Horizon would be able to cover schizophrenia in a different way and that 'current cuts will not mean an end to the occasional dramatised Horizon' ${ }^{84}$

As Milne argued, the makers of 'The Black Pool' and the BBC had different experiences of the parents' reactions. Following the negative press in October 1978, Campbell-Jones wrote to the victims' parents in order to reassure them about Horizon's motives and the fact that the children would not be shown or named. ${ }^{85}$ Plater noted that a petition, sent to the Director General by Clegg in December, 'was not signed by the parents, nor did they respond to considerable pressure from the newspapers to involve themselves in the controversy'. ${ }^{86}$ Files at the $\mathrm{BBC}$ to an extent explain the $\mathrm{BBC}$ 's different understanding. However, beyond the local details of the 'ban', the issues raised by the nature of 'The Black Pool' and responses to it remain thought-provoking.

\section{Conclusion: affect and knowledge}

In December 1978, Campbell-Jones described 'The Black Pool' as 'a unique documented record of the logic of a man going mad. It has altered my perspective of mental illness. I hope it will others. ${ }^{, 87}$ The fact that the same programme was being discussed as a 'documented record' and in terms of its 'emotional overtones' underlines docudrama's specific qualities in 
relation to issues of knowledge. Many British docudramas arose from current affairs strands packaging investigations as drama to address large audiences and their emotions, producing affect. However, as discussed earlier, subjectivity and fictional approaches are not intrinsically separate from documentary: as Elizabeth Cowie observed, documentary is 'an embodied storytelling' that 'engages us with the actions and feelings of social actors' ${ }^{88}$ 'The Black Pool' does not deploy captions and interview testimony as documentary-style social evidence; instead, experience is evidence or, as Campbell-Jones stated in interview, 'you do understand how he got to where he got'.

However, 'embodiment' also raises specific issues in docudrama, given that reconstruction involves the presence of the actor as a 'body too many' as Paget explains: 'In the body of the actor [...] a kind of excess is enacted'. 'The Black Pool' faced this very issue in the question of how to avoid showing the children. Plater's draft script considered making them invisible by showing Alami's approach from inside their cots, but the finished programme less problematically leaves Alami to move left into off-screen space.

Embodiment is a difficult issue to unravel in 'The Black Pool': the physical space is related to Alami's experience of it but embodying that is a challenge for this form.

Unlike Shipman (ITV1, 9 July 2002), another docudrama about a medical killer, 'The Black Pool' does not construct a narrative around an investigation or reconstruct and analyse the killings, but instead focuses on how it felt to be in Alami's mind, a feeling that produces knowledge. ${ }^{90}$ Cowie discussed the construction of knowledge - the epistemology of the observed and objectified - in relation to Michel Foucault's writing on madness. In Foucault's terms, people 'organize an experience of the truth of madness linked to the possibility of an effective knowledge' and 'the mad person becomes an object of knowledge'. ${ }^{91}$ The relationship between affect and knowledge is central to 'The Black Pool', to docudrama and to documentary. Single drama In Two Minds (BBC1, 1 March 1967) had also featured a 
troubling interweaving of subjectivity and objectivity in the exploration of schizophrenia, but the context of 'The Black Pool' marks it as distinct. ${ }^{92}$ This sensitive and complex set of concerns takes place within an approach that is a type of hybrid, not merely because it combines the features of drama and documentary with their respective associations with affect and evidence, but because 'The Black Pool' is both a science documentary and, specifically, a science docudrama.

Documentary theory continues to untangle the unstable binary between documentary as fact and drama as fiction, or the filmmaker/audience agreement that, as observed by Kilborn and Izod, sees documentary 'raw material' as coming from 'the socio-historical world' and not 'primarily from the creative imagination of an authoring agent' ${ }^{93}$ Silverstone notes that a Horizon documentary cannot be 'an empirical truth, a reflective truth which was somehow guaranteed by the presence of the camera'; instead its 'documentary truth' is 'the product of two great falsehoods', namely subjective, authored techniques in filming and editing. ${ }^{94}$ In turn, narrative expectations, the cultures of television, the $\mathrm{BBC}$ and 'the particular history and identity of Horizon' combined to 'define an entirely distinct kind of cultural work' ${ }^{95}$ Unsurprisingly, therefore, as Vincent Campbell notes, 'fundamental critiques of documentary's claims to the real within documentary theory' that have developed since the 1990s have resulted in 'growing critical attention to science documentary'. ${ }^{96}$ The story of 'The Black Pool' illustrates the need for more work in this area.

In interview, Campbell-Jones did not feel that science documentary was necessarily different from documentary as a whole but noted that it is 'incumbent on a science producer to get it done accurately' because it has to see off competing claims, for example when covering climate change. Therefore, he described it as 'evidence-based medicine'. 'The Black Pool' is certainly 'evidence-based', but mapping its display of evidence is potentially problematic not only because it is a science docudrama but also because of the specific 
approach that it takes. Its fictive subjectivity, skewed perspectives and potential for affect are part of its presentation of evidence. Its creative choices are to an extent inherent in science documentary, given Silverstone's contention that science and television 'have different ways of speaking and of addressing the world', one in literary culture and one in oral culture. ${ }^{97}$ Documentaries contain two narrative dimensions - 'argument and story', with argument involving 'the rational demonstration of a case' tied with 'empirical reality' and persuasive 'classical rhetoric' - and they 'tell stories as well as construct arguments'. ${ }^{98}$

'The Black Pool' is therefore not unique in combining argument and story, but the intersections make it troubling: its simultaneously internal and external nature, its primary mobilisation of affect in service of argument rather than as a conventional marker of story. We do not share Alami's subjective perceptions or share his feelings but instead see his subjective perceptions, observing them as evidence, as if emotion serves as documentary value or his construction of his own story operates as the programme's argument. Viewing 'The Black Pool' today, this complex aesthetic, the attempt to objectively render subjective experience, is occasionally unsettling but provides a reminder of the tensions in play around the search for an appropriate approach with which to handle such a difficult subject.

\section{Acknowledgements}

Many thanks to Simon Campbell-Jones and Suzanne Campbell-Jones. Thanks also to the Hull History Centre, BBC Written Archives Centre (in particular Louise North), the National Library of Scotland, the British Library and Derek Paget.

\section{Notes}

${ }^{1}$ This article uses the term 'docudrama', which standardises a wide range of labels. Without changing historical usage - the article retains terms such as 'drama-documentary' in quotations from sources - this standardisation reflects current scholarship, following the 
second edition of Derek Paget's key text No Other Way To Tell It: Docudrama on film and television (Manchester, 2011). This labelling does not disavow distinctions in practice: see Tobias Ebbrecht-Hartmann and Derek Paget (editors), Docudrama on European Television: A Selective Survey (Basingstoke, 2016).

${ }^{2}$ Simon Campbell-Jones, interviewed by David Rolinson, Bath, 30 October 2014 - all subsequent quotations from Simon Campbell-Jones are taken from this interview, unless otherwise stated.

${ }^{3}$ Alan Plater, Lost Horizon, New Statesman, 25 April 1980, 642.

${ }^{4}$ The War Game, a docudrama written, produced and directed by Peter Watkins, examined Britain's preparedness for nuclear war, and its level of public education in nuclear deterrent policy, by imagining a nuclear attack on Britain and its aftermath. Intended for BBC1 transmission in 1965 it was withheld until BBC2 screened it, during nuclear-themed season 'After the Bomb', on 1 August 1985. Brimstone \& Treacle, a drama written by Dennis Potter, produced by Kenith Trodd and directed by Barry Davis, portrayed a man who may be the Devil infiltrating a suburban family. Intended for BBC1 transmission as a Play for Today in 1976, it was not shown until a BBC1 screening, during a Potter season, on 25 August 1987. Scum, a docudrama which exposed conditions in borstals (youth detention centres), was written by Roy Minton, produced by Margaret Matheson and directed by Alan Clarke for transmission as a BBC1 Play for Today in 1977 but was not shown until BBC2 screened it, in a posthumous Clarke tribute season, on 27 July 1991. On the publicity tactics used by the makers of Scum and Brimstone \& Treacle, see respectively Dave Rolinson, Alan Clarke (Manchester, 2005), 74-97, and Dennis Potter, edited by Ian Greaves, David Rolinson and John Williams, The Art of Invective: Selected Non-Fiction 1953-94 (London, 2005). 
${ }^{5}$ Plater, Lost Horizon, 641-2. The title of this current article places 'banning' in scare quotes to indicate the use of 'banned' by the programme's makers including Plater here, and by the press, instead of the more neutral 'untransmitted'.

6 'The Black Pool' is listed with censored and banned programmes in Rolinson, Alan Clarke, 86.

${ }^{7}$ This fact was published widely in press coverage, as in the anonymous articles: Accused doctor son of holy man, Sun, 19 February 1972, 5; Doctor accused of hospital stabbing is son of Mufti, Daily Telegraph, 19 February 1972, 13; Mufti's son is accused of killing baby, Times, 19 February 1972, 1.

${ }^{8}$ Susie Dewar, Medical Ethics, memo to Chris Brasher, 7 February 1973, 1-6. University of Hull Alan Plater archive, Hull History Centre (hereafter HHC) U DPR/4/43.

${ }^{9}$ Anonymous, Inquiry to follow child killings at hospital, Times, 9 June 1972, 4; The Sun Says: Health (2) editorial, Sun, 9 June 1972, 2. On the front page, the same newspaper asked: How did a triple-killer get a job in a hospital?, Anonymous, The monster doctor, Sun, 9 June 1972, 1.

${ }^{10}$ John Roper, Inquiry into killings by doctor not needed, minister states, Times, 6 October $1972,7$.

${ }^{11}$ Ibid.

${ }^{12}$ Samuel C. Lee, Statement by the Deputy Coroner, 18 October 1972, point 6, HHC U DPR/4/43.

${ }^{13}$ For the Protection of the Public, BBC1, 27 March 1973. The documentary was scheduled for 9.25 p.m.-10.15 p.m. and the discussion from 10.15 p.m.-11.00 p.m.

${ }^{14}$ Sean Day-Lewis, Brasher's ammunition against the G M C, Daily Telegraph, 28 March 1973, 15. 
${ }^{15}$ John Roper, Blackpool killings doctor "known to be ill”, Times, 28 March 1973, 1. The statement that Alami was 'totally unfit' came from Brasher's speech at a preview screening.

${ }^{16}$ The Sun Says: Murder in the ward (editorial), Sun, 29 March 1973, 2.

${ }^{17}$ Dewar, 1-6.

${ }^{18}$ Simon Campbell-Jones, The Black Pool, memo to Paul Bonner, 1 December 1978, 1.

Programme Contributors Other than Artists - Convicted Persons, BBC Written Archives Centre (hereafter BBC WAC) R78/2591.

${ }^{19}$ Anonymous, Jordanian doctor repatriated from Broadmoor, Times, 10 December 1976, 6.

${ }^{20}$ Campbell-Jones, The Black Pool, 1. BBC WAC R78/2591.

${ }^{21}$ Sarah Carr, Unit Manager Horizon, memos to Brian Turner, 15 February 1978 and 24 February 1978. Alan Plater 1975-1979 Copyright Registry, BBC WAC RCONT21. Alan Plater, Precis by Alan Plater of manuscript, 1-15, HHC U DPR/3/43.

${ }^{22}$ Alan Plater, The Black Pool: Notes on suggested film by Alan Plater, 1978, HHC U DPR/3/43.

${ }^{23}$ Ibid., 1.

${ }^{24}$ Plater, Lost Horizon, 641.

${ }^{25}$ Steven N. Lipkin, Real Emotional Logic: Film and Television Docudrama as Persuasive Practice (Cardondale and Edwardsville, 2002), 47.

${ }^{26}$ Ibid., 49.

${ }^{27}$ Ibid., 57.

${ }^{28}$ Plater, Notes on suggested film, 1.

${ }^{29}$ Lipkin, 49.

${ }^{30}$ Ibid., 58.

${ }^{31}$ Paget, No Other Way To Tell It, 63.

${ }^{32}$ Ibid., 31 . 
${ }^{33}$ Paul Bonner, draft reply for Ian Trethowan, undated, 1-2, BBC WAC R78/1801, R78/2591.

${ }^{34}$ Campbell-Jones, The Black Pool, 2.

${ }^{35}$ Plater, Lost Horizon, 641.

${ }^{36}$ Bill Nichols, Foreword, in Barry Keith Grant and Jeanette Sloniowski (eds.), Documenting the Documentary: Close Readings of Documentary Film and Video (Detroit, 1998), 13.

${ }^{37}$ Richard Kilborn and John Izod, An Introduction to Television Documentary: Confronting Reality (Manchester, 1997), 29.

${ }^{38}$ Brian Winston, Lies, Damn Lies and Documentaries (London, 2000), 166.

${ }^{39}$ Quoted in Paget, 185.

${ }^{40}$ Quoted in Timothy Boon, Films of Fact: A History of Science in Documentary Films and Television (London, 2008), 232.

${ }^{41}$ Campbell-Jones recently put together a BBC online history of Horizon, available at http://www.bbc.co.uk/historyofthebbc/resources/horizon50.

${ }^{42}$ Aubrey Singer, The Communication of Science, BBC Yearbook (London, 1965), 25-27.

${ }^{43}$ Horizon: Joey: The Autobiography of Joey Deacon, adapted by Brian Gibson and Elaine Morgan from the book Tongue-Tied, directed by Brian Gibson, series editor: Peter Goodchild.

${ }^{44}$ Horizon: The Eddystone Lights, BBC2, written by Alan Plater, directed by Christopher La Fontaine, series editor: Simon Campbell-Jones.

${ }^{45}$ Chris Dunkley, Let my people know, Financial Times, 1 March 1978, 15.

${ }^{46}$ Ibid. The script and shooting schedule for The Eddystone Lights are available in the Plater archive.

${ }^{47}$ Furthermore, Campbell-Jones noted in interview that 'I dislike drama inserts' within conventional documentaries. 
${ }^{48}$ See Dave Rolinson, The Surprise of a Large Town: Depicting Regional Space in Alan Plater's Land of Green Ginger, Journal of British Cinema and Television 4(2) (2007), 285306; also, David Rolinson, Studio as Hybridised Community Space: For the Love of Albert, Critical Studies in Television, 10(3) (2015), 5-22.

${ }^{49}$ Plater, Notes on suggested film, 1.

${ }^{50}$ Alan Plater, The Black Pool typescript with deletions, HHC U DPR/3/43, 1.

${ }^{51}$ Plater, The Black Pool, 86.

${ }^{52}$ BBC WAC R78/2591. Given the sensitivity of some of the correspondence between the $\mathrm{BBC}$ and people outside the $\mathrm{BBC}$, this article maintains the confidentiality of the latter when their correspondence has only been accessed in the BBC's files. Correspondents are named when letters were quoted in the press.

${ }^{53}$ Charles Stewart, Amazing secret of film on butchered babies, Lancashire Evening Post, 3 October 1978, 1.

${ }^{54}$ Anonymous, Comment editorial: A question of taste..., Lancashire Evening Post, 3 October 1978, 1.

${ }^{55}$ Plater, Lost Horizon, 641. A reader criticised the story for its 'irresponsibility', which he felt was characteristic of the newspaper - D. Clarke, Article not justified, Lancashire Evening Post, 12 October 1978, 12. Campbell-Jones found other local media coverage reasonable, such as that of the West Lancs Evening Gazette - Campbell-Jones, The Black Pool, 3. ${ }^{56}$ Walter Clegg, quoted in Stewart, Amazing secret of film, 1. ${ }^{57}$ A question of taste..., 1.

${ }^{58}$ Anonymous, Rees: I'll probe TV horror film, Lancashire Evening Post, 4 October 1978, 1. The newspaper approached him while he was making an official visit nearby. ${ }^{59}$ Ibid. 
${ }^{60}$ Ian Trethowan, letter to Walter Clegg, 1 November 1978, BBC WAC R78/1801. Parts of the letter to Clegg were made public by Julian Allitt, BBC boss backs programme on baby killings, Lancashire Evening Post, 9 November 1978, 1.

${ }^{61}$ Bill Nichols, Representing Reality: Images and Concepts in Documentary (Bloomington, 1991), 3-4.

${ }^{62}$ Plater, Lost Horizon, 641.

${ }^{63}$ Campbell-Jones, The Black Pool, 2, BBC WAC R78/2591.

${ }^{64}$ The four MPs were Peter Blaker, Walter Clegg, Edward Gardner and Norman Miscampbell; some of these and other MPs contacted the BBC individually. This article's account of MPs' actions omits information from the BBC's archives in favour of published sources: Plater, Lost Horizon, 641; Anonymous, Commons bid to block Lancs death film, Lancashire Evening Post, 8 November 1978, 1; Allitt, BBC boss backs programme on baby killings, 1; Anonymous, Alami: Commons Storm Threat, Blackpool Herald, 10 November 1978, 2; Allitt, MPs team up to halt film, Lancashire Evening Post, 11 November 1978, 1; Allitt, Ban this hospital deaths film - MPs, Lancashire Evening Post, 24 November 1978, 13. ${ }^{65}$ Paul Bonner, memo to Ian Trethowan, undated, BBC WAC R78/1801 and R78/2591. ${ }^{66}$ Campbell-Jones, memo to Bonner, 1 December 1978, BBC WAC R78/2591.

${ }^{67}$ Paul Bonner, memo to Director General's Secretary, 7 December 1978, BBC WAC R78/1801.

${ }^{68}$ Plater Lost Horizon, 641.

${ }^{69}$ Ian Trethowan, letter, 5 January 1979, BBC WAC R78/1801.

${ }^{70}$ Board of Management minutes, 8 January 1979, item 16, BBC WAC R78/2591.

${ }^{71}$ Board of Management minutes, 18 December 1978, item 905, BBC WAC R78/2591.

72 Julian Allitt, Has BBC paid Dr Alami?, Lancashire Evening Post, 1 December 1978, 7. 
${ }^{73}$ Horizon: A New Green Revolution?, BBC2, 23 January 1984. However, Silverstone notes that 'An Horizon film is expected to take some seventeen consecutive weeks to produce' Roger Silverstone, Framing Science: The Making of a BBC Documentary (London, 1985), 161.

${ }^{74}$ Plater, Lost Horizon, 641.

${ }^{75}$ Ibid. The archives and interview with Campbell-Jones present other expert praise for the programme.

${ }^{76}$ Daily Mail Reporter, Death drama is axed, Daily Mail, 23 June 1979, 10.

${ }^{77}$ Paul Donovan, The shows that stayed on the shelf..., Daily Mail, 30 June 1979, 17. Earlier, a Guardian report on the BBC's reluctance to repeat or sell abroad their controversial docudrama Law and Order (BBC2, 6-27 April 1978) noted that the BBC had 'reaffirmed its decision earlier in the year' to cancel the Horizon episode - Staff Reporter, BBC rejects law drama export, The Guardian, 25 June 1979, 4. Article Five, a drama written by Brian Phelan, produced by Anne Head and directed by John Bruce, examined British complicity in torture. Made for BBC2's Centre Play strand for 1975 transmission, it was never broadcast. Solid Geometry, a drama written by Ian McEwan, adapting his own short story, experimentally combined mathematics with relationships and sexuality. It was written for BBC2's The Other Side strand, series producer W. Stephen Gilbert, but the BBC cancelled it days before its planned studio recording in 1979. A version written and directed by Denis Lawson was later made for Channel 4 and broadcast on 28 November 2002.

${ }^{78}$ Alan Plater, Joining the banned, annotated draft version of Lost Horizon (1980), HHC U $\mathrm{DPR} / 4 / 43$.

${ }^{79}$ Alasdair Milne, letter to Alan Plater, 15 February 1980, quoted in Plater, Lost Horizon, 641.

${ }^{80}$ Alan Plater, letter to Alasdair Milne, 18 February 1980, HHC U DPR/4/43. 
${ }^{81}$ Alasdair Milne, letter to Alan Plater, 25 February 1980, HHC U DPR/4/43.

${ }^{82}$ Simon Campbell-Jones, letter to Alan Plater, 7 March 1980, HHC U DPR/4/43.

${ }^{83}$ Alasdair Milne, postscript to Plater, Lost Horizon, 642. See also Plater, letter to Bruce

Page, 17 March 1980; Plater, Joining the banned, HHC U DPR/4/43.

${ }^{84}$ Paul Bonner, letter to Alan Plater, 25 July 1980, HHC U DPR/4/43.

${ }^{85}$ Campbell-Jones, The Black Pool, 3, BBC WAC R78/2591.

${ }^{86}$ Plater, Lost Horizon, 641.

${ }^{87}$ Campbell-Jones, The Black Pool, 4, BBC WAC R78/2591.

${ }^{88}$ Elizabeth Cowie, Recording Reality, Desiring the Real (Minneapolis \& London, 2011), 3.

${ }^{89}$ Paget, No Other Way To Tell It, 158.

${ }^{90}$ Shipman, a Yorkshire TV production for ITV1, written by Michael Eaton, produced by Nick Finnis, directed by Roger Bamford.

${ }^{91}$ Interview with Michel Foucault, quoted in Cowie, 55.

${ }^{92}$ The Wednesday Play: In Two Minds - influenced by the work of R.D. Laing, this was written by David Mercer, produced by Tony Garnett and directed by Ken Loach.

${ }^{93}$ Kilborn and Izod, 4-5.

${ }^{94}$ Silverstone, 87-88.

${ }^{95}$ Ibid., 167.

${ }^{96}$ Vincent Campbell, Science, Entertainment and Television Documentary (Basingstoke, 2016), 33.

${ }^{97}$ Silverstone, 163.

${ }^{98}$ Ibid., 169-170. 
David Rolinson is Lecturer in Film and Television at the University of Stirling. He is the author of Alan Clarke (Manchester, 2005) and co-editor of a collection of Dennis Potter's writing, The Art of Invective: Selected Non-Fiction 1953-94 (London, 2015). He edits the website www.britishtelevisiondrama.org.uk. 